\title{
Ocena gleb piaszczystych o opadowo-retencyjnym typie zasilania wodą na podstawie badania eksperymentalnego dotyczącego podsiąku kapilarnego
}

\section{Assessment of sandy soils with a rainfall-retention type of water supply based on an experimental study on capillary rise}

Zarys treści

W eksperymencie wykorzystano piasek luźny drobnoziarnisty. Potwierdzono, że podsiąk kapilarny zwiększa wilgotność gleby i spowalnia przepływ wód opadowych. W artykule wykazano, że podsiąk kapilarny występuje także w glebach wytworzonych z piasku luźnego. W glebach piaszczystych występowanie wód gruntowych jest bardzo istotne, ponieważ wpływa to na zwiększenie wilgotności w całym profilu glebowym. Pozbawienie gleby piaszczystej możliwości wykorzystania wód gruntowych (np. w granicach leja depresyjnego), to uniemożliwienie najlepszego wykorzystania wód opadowych i spowodowanie gorszych warunków wilgotnościowych.

Słowa kluczowe Podsiąk kapilarny, uwilgotnienie gleby, piasek luźny drobnoziarnisty, lej depresyjny.

Abstract

Fine-grained sand was used in the experiment. It was confirmed that the capillary underflow increases soil moisture and slows down the flow of rainwater. The article demonstrates that capillary rise also occurs in soils made of sand. In sandy soils, the occurrence of groundwater is very important, because it affects the increase of humidity in the entire soil profile. Depriving sandy soil of the possibility of using groundwater (e.g. within the depression cone) prevents the best use of rainwater and causes worse humidity conditions.

Keywords Capillary rise, soil moisture, fine sand, depression cone.

\section{Wprowadzenie}

Przez stulecia w glebach Polski występowały okresowe wahania poziomu wód gruntowych. Jednak corocznie po miesiącach bardziej suchych zazwyczaj nadchodziła pora obfitych opadów atmosferycznych (śnieżna zima lub deszczowe lato), a wtedy następowało uzupełnienie lub wzbogacenie zasobów wód gruntowych.

Obecnie borykamy się z suszą glebową, na obszarach centralnej Polski, gdyż roczna suma opadów była relatywnie niska. W ostatniej dekadzie odnotowano dużą zmienność odnośnie rocznej sumy opadów. W latach 2010, 2014 i 2016 była ona zadowalająca, natomiast lata 2011, 2015, 2018 i 2019 w Polsce środkowej charakteryzowały się niskimi wartościami (tab. 1).

Należy zauważyć, że w każdym roku z minionych dziesięciu lat, odnotowano większą roczną sumę opadów atmosferycznych, na obszarach szeroko rozumianego otoczenia KWB "Bełchatów” (na południe od Bełchatowa i Szczercowa) w porównaniu do obszarów rozproszonych odkrywek KWB „Konin”, zlokalizowanych na północ od Konina (tab. 1).

Z powodu eksploatacji złóż węgla brunatnego w okolicach Konina i Bełchatowa, pojawił się dodatkowy problem rozległego leja depresji hydrologicznej. Jest on efektem działania opaski odwadniającej złoże, na którą składają się setki studni głębinowych. Muszą one odebrać wodę poniżej głębokości zalegania złoża węgla brunatnego. Takie działanie powoduje, że wokół mniejszych i większych kopalni odkrywkowych, na obszarze od kilkudziesięciu do kilkuset $\mathrm{km}^{2}$, studnie gospodarcze okolicznych wsi są pozbawione wody.

Lej depresyjny, który powstał w Polsce środkowej w wyniku odwadniania złoża węgla brunatnego KWB „Bełchatów” wpłynął na obniżenie zasobów wód powierzchniowych i zmniejszenie odpływu rzecznego. Wraz ze wzrostem jego udziału w zlewni zwiększała się skala zachodzących zmian. Wycofywanie się leja depresyjnego związane jest z przesuwaniem frontu prac górniczych i odwodnieniowych, co powoduje stopniowe odtwarzanie się zasobów wodnych. Procesy te prześledzić można na przykładzie analizy zmian zachodzących w przepływach górnej Widawki i odpływie w zlewni w latach 1976-2002. Największe zmniejszenie charakterystyk hydrologicznych przypada na lata 1991-1994, kiedy to miał miejsce największy udział leja depresyjnego w zlewni. Od 1995 roku następuje stopniowy wzrost odpływu oraz zmniejsza się wpływ leja depresyjnego, co związane jest z jego regresją w zlewni Widawki (Wachowiak 2004). Podobne zagadnienia dotyczące wpływu leja depresyjnego okręgu bełchatowskiego, ale w innych okresach czasowych badali również Jeż i in. 
Tabela 1. Roczne sumy opadu atmosferycznego na obszarach otaczających KWB „Bełchatów” i KWB „Konin” w latach 2010-2019 (oprac. własne na podstawie danych IMGW)

Table. 1. Annual total precipitation in the years 2010-2019 in the areas surrounding KWB "Bełchatów" and KWB "Konin" (own study according to IMGW data)

\begin{tabular}{|c|c|c|}
\hline \multirow{2}{*}{ Rok } & \multicolumn{2}{|c|}{ Roczne sumy opadów [mm] } \\
\hline & $\begin{array}{c}\text { na obszarze wydobycia węgla brunatnego } \\
\text { przez KWB „Bełchatów” }\end{array}$ & $\begin{array}{c}\text { na obszarze wydobycia węgla brunatnego } \\
\text { przez KWB „Konin” }\end{array}$ \\
\hline 2010 & $750-800$ & $680-710$ \\
\hline 2011 & $480-520$ & $390-430$ \\
\hline 2012 & $510-540$ & $480-510$ \\
\hline 2013 & $580-630$ & $540-570$ \\
\hline 2014 & $600-650$ & $430-460$ \\
\hline 2015 & $380-420$ & $300-340$ \\
\hline 2016 & $650-700$ & $500-550$ \\
\hline 2017 & $490-540$ & $440-470$ \\
\hline 2018 & $450-500$ & $350-390$ \\
\hline 2019 & $380-430$ & $340-380$ \\
\hline
\end{tabular}

Źródło: oprac. własne/Source: own study.

(1997) w zlewni Kręcicy. Szczegółowej analizie poddano zmiany sieci hydrograficznej, wód podziemnych i odpływu. Ukazano kierunki i siłę zmian warunków wodnych w latach 1981-1989. Autorzy stwierdzili jednoznacznie i dobitnie wskazali na kierunki i siłę przemian spowodowanych przez KWB „Bełchatów” i przedstawili wpływ antropopresji na mechanizm obiegu wody w zlewni Kręcicy. Z kolei Kozek i Tomaszewski (2018) badali wschodnią część zlewni Warty, która objęta jest częściowo lejem depresyjnym, związanym z wydobyciem węgla brunatnego w KWB „Bełchatów” oraz zrzutami wód kopalnianych do systemu Widawki. Także Tomaszewski (2014) zaprezentował podobne wyniki badań nad dynamiką niedoborów odpływu niżówkowego w rzekach poddanych silnej antropopresji. Efekty działalności górnictwa odkrywkowego w regionie bełchatowskim obserwowane były w zlewni Widawki, zamkniętej przekrojem w Rogóźnie i Podgórzu. Wpływ kopalń regionu konińskiego, wywołanego przez KWB „Konin” ukazano na przykładzie zlewni Kiełbaski, badanej do wsi Kościelec. Podstawowe zmiany w naturalnym obiegu wody, wiążą się w tym regionie z koniecznością ciągłego odwadniania górotworu w celu umożliwienia eksploatacji złoża węgla brunatnego. W efekcie rozwinęły się ogromne leje depresyjne, z których wody odpompowywane są poza obszar sztucznie wywoływanej depresji (Tomaszewski 2011, 2012, 2014).

Na obszarach wokół kopalni węgla brunatnego (KWB „Bełchatów” i KWB „Konin”), mieszkający tam rolnicy borykają się z wpływem leja depresji hydrologicznej na gleby orne, a szczególnie na ich produktywność. Opinie na ten temat budzą wiele kontrowersji, ponieważ inaczej oceniają to rolnicy, którzy aktywnie prowadzą gospodarkę rolną w zmienionych warunkach wilgotnościowych, natomiast zarządzający kopalniami odkrywkowymi od- pierają zarzuty o wyrządzanych szkodach. A przecież gleby są dynamicznymi układami, których reakcja na przesuszenie zależy od wielu czynników (Lekan i Terelak 2000).

Biskupski i in. (2008) podają, że nie stwierdzono negatywnego wpływu oddziaływania odkrywki KWB „Bełchatów" na zmiany w uwilgotnieniu gleb ornych bez względu na oddalenie od odkrywki. Wahania wilgotności gleb w okresie badawczym zależały przede wszystkim od wielkości i rozkładu opadów atmosferycznych. W celu określenia wpływu oddziaływania kopalnianego leja depresji na przyległe tereny użytkowane rolniczo niezbędne będzie ciągłe monitorowanie gleb, obejmujące pomiary ich uwilgotnienia $w$ dłuższym przedziale czasowym (Biskupski i Włodek 2011).

Lekan i Terelak (2000) twierdzą, że reakcja gleb na przesuszające oddziaływanie leja depresji hydrologicznej i związane z tym plonowanie roślin zależy przede wszystkim od pierwotnego typu i charakteru gospodarki wodnej gleby, na co wpływa skład granulometryczny gleby oraz budowa profilu glebowego. Decydują one o zdolności gleby do magazynowania wody. Oddziaływanie leja depresji zależy także od rodzaju użytkowania terenu i uprawianych roślin, przebiegu pogody w okresie wegetacji, w tym głównie ilości i rozkładu opadów (podtrzymanie wilgotności wierzchnich poziomów gleby) na terenach objętych skutkami odwodnienia.

Wielu badaczy twierdziło, że pierwotny typ gospodarki wodnej gleb w najistotniejszy sposób decyduje o ich właściwościach wodnych. Przyjmują oni podział gospodarki wodnej gleb na trzy podstawowe typy, tj.:

a) opadowo-retencyjną (OR) o przeciętnym zaleganiu wód gruntowych głębiej niż 2,0 metry poniżej powierzchni terenu (m p.p.t.), 
b) opadowo-gruntowo-wodną (OGW) o zaleganiu wód gruntowych na głębokości 0,7-2,0 m p.p.t., ale także

c) gruntowo-wodną (GW), o zaleganiu wód gruntowych płycej niż 0,7 m p.p.t. (Krajewski i in. 1969, Ślusarczyk 1985a i 1985b).

Wynika z tego, że o zaspokojeniu potrzeb wodnych roślin w poszczególnych typach gospodarki wodnej gleb decydują różne czynniki. Na obszarze wpływu KWB „Bełchatów” już w pierwszych latach działalności, tj. od 1978 roku były prowadzone badania naukowe, w których wykonywano kompleksową ocenę zmian wilgotności gleb ornych oraz plonowania roślin uprawnych (Sarnacka i in. 1987). Wyniki tych 10-letnich badań wykazały, że lej depresji hydrologicznej nie miał istotnego wpływu na zmiany w uwilgotnieniu gleb o opadowo-retencyjnym typie gospodarki wodnej (OR). Badania wykazały także, że stan uwilgotnienia gleby nie zależał od położenia w obrębie leja depresyjnego. W obydwu przypadkach wilgotność gleb zależała od ilości opadów atmosferycznych oraz od zdolności retencyjnej samej gleby (Ślusarczyk 1985a, Sarnacka i in. 1987).

Lekan i Terelak (2000) podają, że w glebach o typie gospodarki wodnej OR prawie całe zapotrzebowanie gleb i roślin na wodę jest pokrywane z opadów atmosferycznych oraz wody zmagazynowanej w glebie. Podkreślają wpływ uziarnienia na te procesy oraz twierdzą, że głębokość zalegania wód gruntowych nie ma decydującego wpływu na wzrost i plonowanie roślin. Z kolei w glebach o typie gospodarki wodnej GW potrzeby wodne gleb i roślin mogą być niemal w pełni zaspokajane z zasobów wód gruntowych, a kapilarny podsiąk wody sięga poziomów wierzchnich. Gleby o gospodarce wodnej OGW mają charakter pośredni. W zaspokojeniu potrzeb wodnych tych gleb i uprawianych roślin ważną rolę odgrywa glebowy podsiąk kapilarny (Lekan i Terelak 2000).

W naukach o glebie, bonitacja dotyczy oceny jakości gleby pod względem wartości użytkowej, uwzględniającej żyzność gleby, stosunki wodne w glebie, stopień kultury rolnej gleby i trudność uprawy w powiązaniu z agroklimatem, rzeźbą terenu oraz niektórymi elementami stosunków gospodarczych.

W zależności od przyjętej bonitacji zespół cech wyraża się w klasach lub punktach. Przeprowadza się ją w celu zakładania jednolitej ewidencji gruntów, będącej podstawą określenia wymiaru podatku gruntowego, scalania gruntów oraz racjonalnego ich wykorzystania na cele nierolnicze. Jednym z podstawowych kryteriów wyznaczania klas bonitacyjnych jest ocena stanu wód gruntowych.

Uwzględnia się następujące kryteria:

- typ i podtyp gleby, rodzaj, gatunek, miąższość poziomu próchnicznego i zawartość próchnicy glebowej, odczyn gleby, skład chemiczny, właściwości fizyczne, poziom wód gruntowych i ewentualne oglejenie,

- stosunki wilgotnościowe uwarunkowane położeniem w terenie,

- wysokość nad poziom morza (dla bonitacji gleb wyżynnych i gleb górskich).
W Komentarzu do tabeli klas gruntów (1963), w szczegółowym opisie profili glebowych jest też bardzo często odwołanie do rzeźby terenu, miąższości poziomu próchnicznego oraz warunków wodnych - jako czynników wpływających na jakość rolniczą gleb (Smreczak i Łachacz 2019).

W nowym wydaniu Urzędowej Tabeli Klas Gruntów, czyli w Załączniku do Rozporządzenia Rady Ministrów (Dz.U. 2012) aż 61 razy występuje zbitka dwóch słów: „wód gruntowych", poprzedzone słowami: poziom, poziomu, poziomie, stan, stanu, odpływu.

Wpływ wód gruntowych na plonowanie i produktywność gleb w okolicach Łodzi, potwierdzają badania na użytkach zielonych (Laskowski i in. 2005a, 2005b, 2006, Trawczyńska i Tołoczko 2005, 2006, Wroński i Tołoczko 2008, Trawczyńska i in. 2009), ale także na gruntach ornych na glebach o zróżnicowanej genezie i położeniu w terenie (Laskowski i Tołoczko 1995, 1998, 2001, 2003, Laskowski i in. 2001b, 2005c, Krysiak i Tołoczko 2004, Niewiadomski i in. 2009, Tołoczko i in. 2009). W innych badaniach obserwowano i określono wpływ wód gruntowych na żyzność siedlisk leśnych w różnych częściach regionu łódzkiego (Laskowski i in. 2001a, Papińska i Tołoczko 2002, Trawczyńska i Tołoczko 2007, Tołoczko i Szmidt 2018). Na podstawie wyników badań i obserwacji można stwierdzić, że wody gruntowe i wilgotność gleby korzystnie wpływały na glebę oraz uprawiane rośliny bez względu na głębokość ich zalegania oraz typ gospodarki wodnej (OR i OGW). Z badań Mosieja (1989) nad plonowaniem traw w uprawie polowej wynika, że wzrost wilgotności gleby o $10 \%$ może spowodować wzrost plonu o 50\%. Także Noworolnik (2010) w oparciu o doświadczenia wazonowe, gdzie utrzymywał w glebie wilgotność na poziomie $60 \%$ pojemności wodnej oraz 30\% pojemności wodnej stwierdził, że uwilgotnienie gleby jest kluczowe dla osiągnięcia większego plonu owsa. Dlatego też nie można lekceważyć oddziaływania wód gruntowych na wilgotność gleby. Zebrane doświadczenie, obserwacje oraz wyniki badań upoważniają do podjęcia działań związanych z prezentowanym poniżej eksperymentem laboratoryjnym.

\section{Założenia eksperymentu}

Ocenie poddano wpływ podsiąku kapilarnego w glebie na jej wilgotność w poziomach powierzchniowych w warunkach laboratoryjnych. Podjęto próbę przełożenia wyników eksperymentu i udowodnienia, że lej depresyjny wpływa niekorzystnie na wilgotność gleby w profilu glebowym gleb lekkich o uziarnieniu piasku. Koncepcja eksperymentu zakładała zbadanie wilgotności części profilu glebowego znajdującego się nad poziomem lustra wody w porównaniu z częścią profilu bez zasięgu lustra wody. Eksperyment zakładał wykorzystanie piaszczystego materiału glebowego najczęściej wykorzystywanego pod zalesienie, a tylko z konieczności wykorzystywanego jako grunty orne. Wybrano piasek luźny drobnoziarnisty, z którego przy dużej staranności wykonania, łatwo można uzyskać jednakowe i jednorodne wypełnienie rur. Uwzględniono rezultaty badań Baranowskiego (1980), 
z których wynika, że (cyt.) stan spulchnienia lub zagęszczenia wpływa na „koncentrację" wody (wilgotność liczoną w \% objętościowych), infiltrację i przepuszczalność wodną gleby oraz podsiąkanie kapilarne i związaną z tym intensywność parowania, a zagęszczenie gleby wpływa na zwiększenie jej zwięzłości.

\section{Wykonanie eksperymentu}

Eksperyment rozpoczęto $\mathrm{w}$ listopadzie 2019 roku przygotowując odpowiednie rury. Miały one długość $66 \mathrm{~cm}$ i wewnętrzną średnicę 10,4 cm. Dno każdej rury posiadało zatyczkę nawierconą 20 otworami (o $\varnothing=8 \mathrm{~mm}$ ), zabezpieczonymi metalową siatką. Zatyczka była przykręcona do rury krótkimi wkrętami. Na dno każdej rury opuszczono okrągły sączek z bibuły filtracyjnej, który swobodnie opadł na jej dno, na metalową siatkę. Było to zabezpieczenie przed wypłukiwaniem piasku podczas przesiąku i podsiąku.

Przygotowano sześć rur z utworem piaszczystym (fot. 1). Materiał do eksperymentu pochodził z wielkiego wyrobiska przy ul. Pomorskiej w Łodzi. Piasek był w pryzmie i przygotowany do prac budowlanych na przesiewaczu bębnowym z sitem plecionym. Uziarnienie piasku podano w kolejnym rozdziale.

Na miejscu napełniono wszystkie rury, a znajdujący się w nich piasek zagęszczono uderzając kilkukrotnie pełną rurą o piaszczyste podłoże. Ponieważ materiał był jednorodny, uznano że takie zagęszczenie będzie odpowiednie dla wszystkich rur. Nie badano gęstości nasypowej, uznano, że jest jednakowa w każdej rurze. Po przeniesieniu rur do samochodu przewieziono je do budynku Wydziału Nauk Geograficznych Uniwersytetu Łódzkiego. Pobrano również dodatkowo piasek w wiadrze w celu oznaczenia aktualnej wilgotności i składu granulometrycznego wraz z udziałem procentowym frakcji szkieletowej (tab. 2, tab. 3). W laboratorium określono aktualną wilgotność piasku pobranego do eksperymentu w trzech powtórzeniach. Wilgotność sypkiego materiału wynosiła 3,5\%. Do określenia wilgotności piasku i procentowego udziału frakcji szkieletowych każdorazowo wykorzystano próbki o masie 300-400 g.

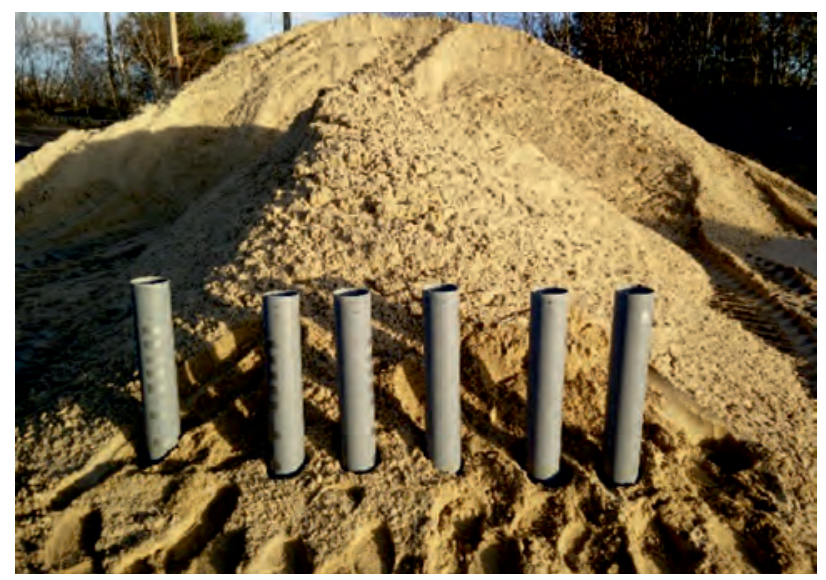

W laboratorium nastawiono podsiąk kapilarny w trzech losowo wybranych rurach. Do okrągłych pudełek wstawiono 3 rury napełnione piaskiem, a następnie do pudełek wlano 2 razy po $400 \mathrm{ml}$ wody w odstępach $30 \mathrm{~min}$. Pierwsze $400 \mathrm{ml}$ wody wsiąkło szybko, a drugie dużo wolniej.

Następnego dnia na powierzchnię 6 rur wlano $300 \mathrm{ml}$ wody, a po upływie 4 godzin ponownie wlano do każdej z rur kolejne $300 \mathrm{ml}$ wody. Spodziewano się, że woda łatwo przesiąknie do dna, jednak ciągle utrzymywała się w sztucznie uformowanym piaszczystym fragmencie profilu glebowego. W 3 rurach przeznaczonych do oceny podsiąku kapilarnego nie zaobserwowano podwyższenia poziomu wody w pojemnikach (pudełkach), a w rurach bez podsiąku (z woreczkami zabezpieczającymi dno rur z zatyczkami przed oddolnym parowaniem) również nie odnotowano nasycenia wodą. Po upływie kolejnej godziny zauważono, że poziom wody w pojemnikach czyniących podsiąk podniósł się, więc woda wsiąkająca sięga coraz głębiej i już stykała się z wodą kapilarnego podsiąku. Aby rozpocząć eksperyment, do trzech rur z podsiąkiem wlano do każdej tylko po $100 \mathrm{ml}$ wody, a do trzech rur bez podsiąku wlano do każdej aż po $300 \mathrm{ml}$ wody-dla pewności, że przesiąk nastąpi. Na tym zakończono odgórne zasilanie wodą. Okazało się już po kilku minutach, że woda zaczęła wyciekać przez mikro nieszczelności woreczków. Tego oczekiwano i w ten sposób uzyskano pewność, że w tych trzech rurach bez podsiąku, piasek jest również wysycony wodą, która grawitacyjnie będzie opuszczać rury. Nadmiar wody usuwano, zarówno z pojemników z podsiąkiem (utrzymując $1 \mathrm{~cm}$ wody w pudełku) oraz spod rur bez podsiąku, które przestawiono na pojedyncze tace. Reasumując - łącznie do trzech rur z podsiąkiem wlano po $700 \mathrm{ml}$ wody, a do rur bez podsiąku aż po $900 \mathrm{ml}$ wody. Wszystkie rury pozostawiono bez dalszej ingerencji i rozpoczęto liczenie upływających godzin eksperymentu, który podzielono na trzy etapy.

Etap 1 - trwał 117 godzin.

Etap 2 - trwał 431 godzin.

Etap 3 - trwał 1002 godziny.

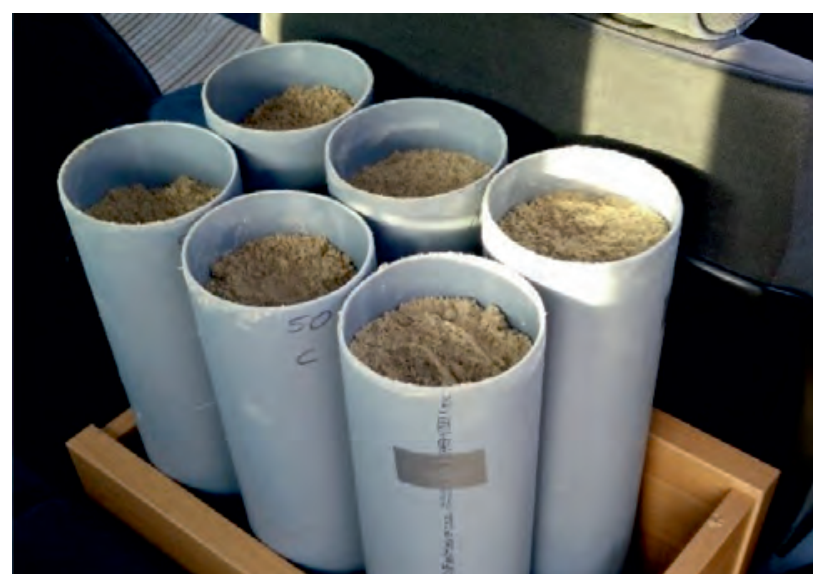

Fot. 1. Przygotowanie eksperymentu (fot. W. Tołoczko, 2019)

Photo 1. Preparation of the experiment (photo by W. Tołoczko, 2019) 
Założono w eksperymencie, że w czasie jego trwania, w rurach $-z$ podsiąkiem kapilarnym i bez podsiąku - woda swobodnie przesiąknie, a od góry będzie wysychać poprzez powierzchnię wystawioną na działanie powietrza z ogrzewanego laboratorium (fot. 2). Tempe-
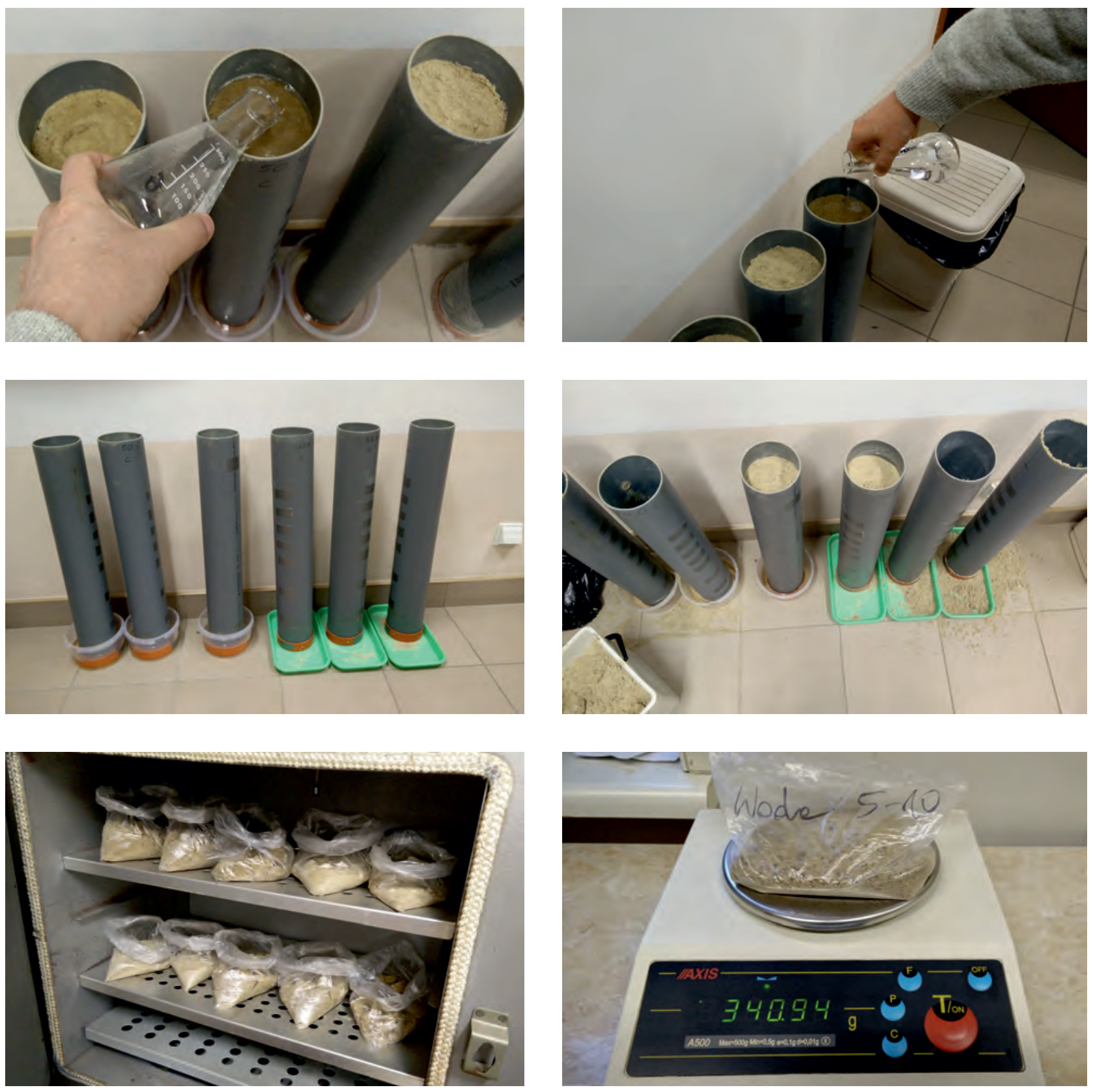

Fot. 2. Wykonanie eksperymentu (fot. W. Tołoczko, 2019)

Photo 2. Conducting the experiment (photo by W. Tołoczko, 2019)

ratura w laboratorium przez wszystkie godziny eksperymentu wynosiła $20-22^{\circ} \mathrm{C}$. Znajdujący się w rurach piasek miał temperaturę pokojową. W eksperymencie działały czynniki takie, jak: grawitacja, parowanie oraz podtrzymywanie wilgotności gleby poprzez podsiąk kapilarny.
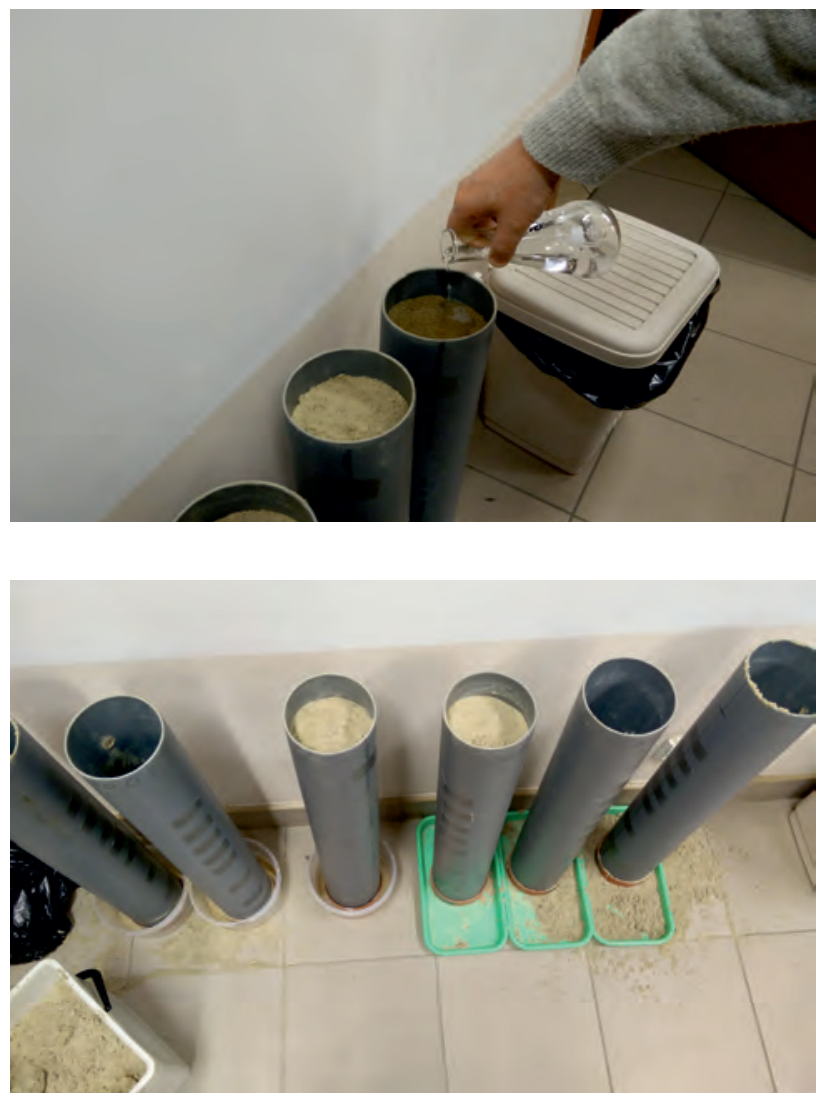


\section{Wyniki i obliczenia}

Wykonano oznaczenia składu granulometrycznego, a wyniki interpretowano według klasyfikacji wykorzystywanej na mapach glebowo-rolniczych (NB 78/9180-11) oraz według klasyfikacji PTG 2008 (PTG 2009).

Tabela 2. Skład granulometryczny wg NB 78/9180-11 Table 2. Grain size composition by NB 78/9180-11

\begin{tabular}{|c|c|}
\hline $\begin{array}{l}\text { Wielkość frakcji } \\
{[\mathrm{mm}]}\end{array}$ & $\begin{array}{c}\text { Udział frakcji } \\
{[\%]}\end{array}$ \\
\hline$>1,0$ & 10 \\
\hline$<1,0$ & 90 \\
\hline $1,0-0,5$ & 17 \\
\hline $0,5-0,25$ & 26 \\
\hline $0,25-0,1$ & 53 \\
\hline $0,1-0,05$ & 1 \\
\hline $0,05-0,02$ & 0 \\
\hline $0,02-0,006$ & 1 \\
\hline $0,006-0,002$ & 0 \\
\hline$<0,002$ & 2 \\
\hline $1,0-0,1$ & 96 \\
\hline $0,1-0,02$ & 1 \\
\hline$<0,02$ & 3 \\
\hline
\end{tabular}

Tabela 3. Skład granulometryczny wg PTG 2008

Table 3. Grain size composition by PTG 2008

\begin{tabular}{|c|c|}
\hline $\begin{array}{l}\text { Wielkość frakcji } \\
{[\mathrm{mm}]}\end{array}$ & $\begin{array}{c}\text { Udział frakcji } \\
{[\%]}\end{array}$ \\
\hline$>2,0$ & 4 \\
\hline$<2,0$ & 96 \\
\hline $2,0-1,0$ & 4 \\
\hline $1,0-0,5$ & 14 \\
\hline $0,5-0,25$ & 28 \\
\hline $0,25-0,1$ & 50 \\
\hline $0,1-0,05$ & 1 \\
\hline $0,05-0,02$ & 1 \\
\hline $0,02-0,006$ & 0 \\
\hline $0,006-0,002$ & 1 \\
\hline$<0,002$ & 1 \\
\hline $2,0-0,05$ & 97 \\
\hline $0,05-0,002$ & 2 \\
\hline$<0,002$ & 1 \\
\hline
\end{tabular}

Do eksperymentu pozyskano materiał glebowy o składzie granulometrycznym piasek luźny, wg NB 78/9180-11 oraz klasyfikacji PTG 2008 (PTG 2009). Uwzględniając szczegółowy podział piasków wg ziarnistości frakcji pia- skowej (PTG 2009), w eksperymencie użyto piasek luźny drobnoziarnisty. W wysuszonej próbce piasku o masie 0,7 kg znaleziono tylko 8 ziaren żwiru o średnicy 3-4 mm (pomiary wykonano suwmiarką noniuszową), a ziarna o średnicy powyżej $4 \mathrm{~mm}$ nie występowały.

Objętość piasku w eksperymencie to objętość walca, czyli iloczyn powierzchni podstawy $\left(\pi \cdot r^{2}\right)$ i wysokości słupa piasku (h): $V=\pi \cdot r^{2} \cdot h=3,142 \cdot 5,22 \mathrm{~cm}^{2} \cdot 63 \mathrm{~cm}$ $=5352 \mathrm{~cm}^{3}=5,35 \mathrm{dm}^{3}$. Należy przyjąć, że w eksperymencie wykorzystano słup piasku o wysokości 0,63 m, który posiadał objętość $5,35 \mathrm{dm}^{3}$.

Eksperyment wykonano w trzech etapach, a uzyskane wyniki przedstawiono w zestawieniu tabelarycznym (tab. 4, tab. 5 i tab. 6). Wilgotność oznaczono pobierając piasek z rury na kolejnych pięciu głębokościach. Pobrano 5 próbek o masie 300-400 g i umieszczano w suszarce, gdzie w temp. $80^{\circ} \mathrm{C}$ przebywały $18-20$ godzin. Obliczenia wykonano według wzoru:

$$
W p=\frac{M p w-M p s}{M p w} \cdot 100 \%
$$

gdzie: Wp - wilgotność piasku [\%], Mpw - masa piasku wilgotnego [g], Mps - masa piasku suchego [g].

Tabela 4. Wilgotność piasku po upływie 117 godzinach od nasycenia wodą (etap 1 eksperymentu)

Table 4. Sand moisture after 117 hours since water saturation (Stage 1 of the experiment)

\begin{tabular}{ccc}
\hline $\begin{array}{c}\text { Głębokość poniżej } \\
\text { powierzchni piasku } \\
\text { w rurze } \\
{[\mathrm{cm}]}\end{array}$ & $\begin{array}{c}\text { Wilgotność piasku } \\
\text { w rurze z podsiąkiem } \\
\text { kapilarnym } \\
{[\%]}\end{array}$ & $\begin{array}{c}\text { Wilgotność piasku } \\
\text { w rurze bez podsiąku } \\
\text { kapilarnego } \\
{[\%]}\end{array}$ \\
\hline $0-5$ & 0,39 & 0,34 \\
\hline $5-10$ & 1,01 & 0,86 \\
\hline $20-25$ & 3,99 & 3,77 \\
\hline $30-35$ & 7,84 & 6,04 \\
\hline $40-45$ & 16,29 & 10,14 \\
\hline$<60$ & lustro wody & brak wody \\
\hline
\end{tabular}

Tabela 5. Wilgotność piasku po 431 godzinach od nasycenia wodą (etap 2 eksperymentu)

Table 5. Sand moisture after 431 hours since water saturation (Stage 2 of the experiment)

\begin{tabular}{ccc}
\hline $\begin{array}{c}\text { Głębokość poniżej } \\
\text { powierzchni piasku } \\
\begin{array}{c}\text { w rurze } \\
{[\mathrm{cm}]}\end{array}\end{array}$ & $\begin{array}{c}\text { Wilgotność piasku } \\
\text { w rurze z podsiąkiem } \\
\text { kapilarnym } \\
{[\%]}\end{array}$ & $\begin{array}{c}\text { Wilgotność piasku } \\
\text { w rurze bez podsiąku } \\
\text { kapilarnego } \\
{[\%]}\end{array}$ \\
\hline $0-5$ & 0,29 & 0,26 \\
\hline $5-10$ & 0,99 & 0,84 \\
\hline $20-25$ & 3,61 & 3,14 \\
\hline $30-35$ & 6,38 & 5,41 \\
\hline $40-45$ & 11,31 & 8,12 \\
\hline$<60$ & lustro wody & brak wody \\
\hline
\end{tabular}


Tabela 6. Wilgotność piasku po 1002 godzinach od nasycenia wodą (etap 3 eksperymentu)

Table 6. Sand moisture after 1002 hours since water saturation (Stage 3 of the experiment)

\begin{tabular}{ccc}
\hline $\begin{array}{c}\text { Głębokość poniżej } \\
\text { powierzchni piasku } \\
\text { w rurze } \\
{[\mathrm{cm}]}\end{array}$ & $\begin{array}{c}\text { Wilgotność piasku } \\
\text { w rurze z podsiąkiem } \\
\text { kapilarnym } \\
{[\%]}\end{array}$ & $\begin{array}{c}\text { Wilgotność piasku } \\
\text { w rurze bez podsiąku } \\
\text { kapilarnego } \\
{[\%]}\end{array}$ \\
\hline $0-5$ & 0,13 & 0,12 \\
\hline $5-10$ & 0,91 & 0,79 \\
\hline $20-25$ & 3,39 & 3,01 \\
\hline $30-35$ & 5,78 & 4,91 \\
\hline $40-45$ & 9,38 & 5,79 \\
\hline$<60$ & lustro wody & brak wody \\
\hline
\end{tabular}

W kolumnach tabel 4, 5 i 6 zaprezentowano wyniki pomiarów wilgotności na odpowiedniej głębokości. We wszystkich etapach eksperymentu, próbki piasku w rurach z podsiąkiem miały większą wilgotność niż piasek z odpowiednich poziomów w rurach bez podsiąku, także piasek z poziomu wierzchniego, (0-5 cm od powierzchni) w najdłużej trwającym eksperymencie, czyli po 1002 dniach.

$\mathrm{Na}$ kolejnych wykresach zaprezentowano wyniki pomiarów z trzech etapów eksperymentu, z tej samej głębokości (ryc. 1, ryc. 2 i ryc. 3).

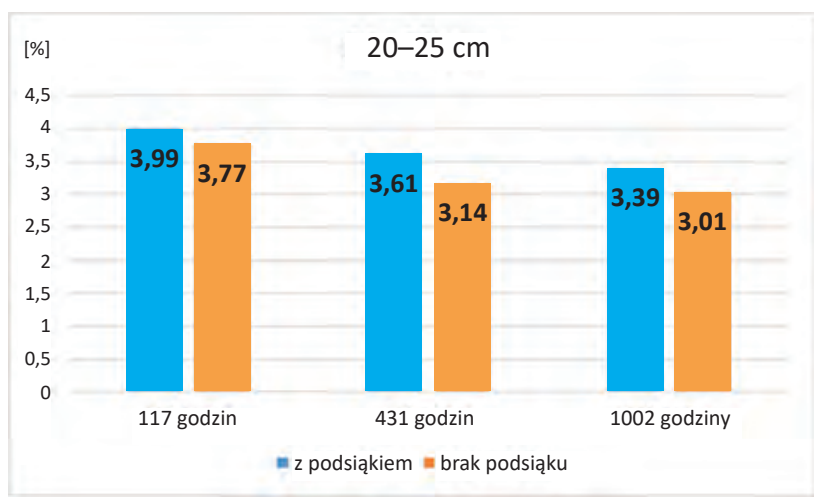

Ryc. 1. Wilgotność piasku na głębokości $20-25 \mathrm{~cm}$ od powierzchni z podsiąkiem i bez podsiąku w trzech etapach eksperymentu

Fig. 1. Sand moisture at the depth of $20-25 \mathrm{~cm}$ from the surface with or without the capillary rise in three stages of the experiment

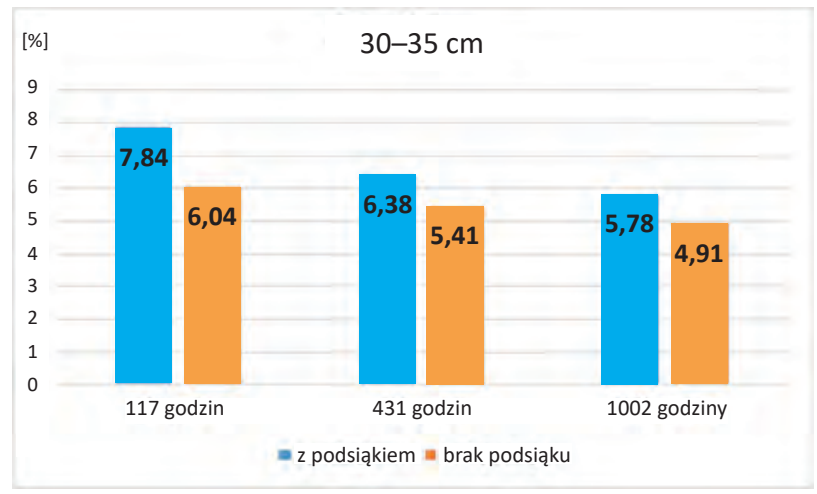

Ryc. 2. Wilgotność piasku na głębokości 30-35 cm od powierzchni z podsiąkiem i bez podsiąku w trzech etapach eksperymentu

Fig. 2. Sand moisture at the depth of $30-35 \mathrm{~cm}$ from the surface with or without the capillary rise in three stages of the experiment

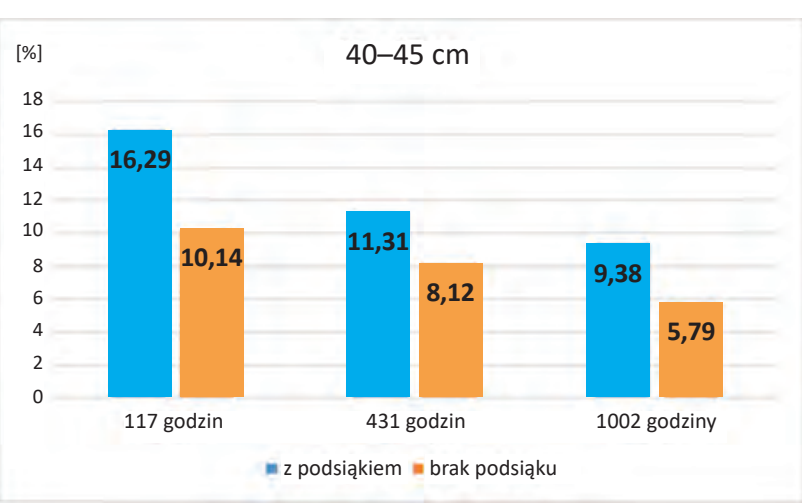

Ryc. 3. Wilgotność piasku na głębokości $40-45 \mathrm{~cm}$ od powierzchni z podsiąkiem i bez podsiąku w trzech etapach eksperymentu

Fig. 3. Sand moisture at the depth of $40-45 \mathrm{~cm}$ from the surface with or without the capillary rise in three stages of the experiment

Dla zwiększenia wiarygodności uzyskanych wyników, do rur z podsiąkiem wlano po $700 \mathrm{ml}$ wody (niebieski słupek wykresu), a do rur bez podsiąku wlano po $900 \mathrm{ml}$ wody (pomarańczowy słupek wykresu). W rurach z podsiąkiem, mimo mniejszej ilości wody wlanej do rur, wilgotność na każdej badanej głębokości była większa niż na tych samych głębokościach w rurach bez podsiąku.

\section{Dyskusja}

Wody gruntowe, na dowolnej głębokości, nawet poniżej 2 metrów, wywierają swego rodzaju wsparcie, poprzez połączenia hydrauliczne związane z siłami kohezji i adhezji. Woda jest utrzymywana w glebie przez siły kohezji, które występują pomiędzy molekułami wody. Siły adhezyjne mają tendencję do powiększania granicznej powierzchni pomiędzy fazą ciekłą a fazą stałą. Ich działanie powoduje zwiększanie hydrofilności i maksymalizowanie zwilżania powierzchni cząstek glebowych (Kowalik 2001). Poprzez utrzymywanie $100 \%$ nasycenia powietrza glebowego parą wodną zmniejsza się tempo odpływu grawitacyjnego wody w głąb profilu glebowego. Obecność wody gruntowej zwiększa wilgotność całego profilu glebowego, aż do poziomu próchnicznego. Im bardziej drobnoziarnisty i zwięzły będzie mineralny materiał glebowy, tym wpływ wód gruntowych na uwilgotnienie będzie większy (Grabowska-Olszewska, Siergiejew 1977, Kowalik 2001).

Gleby wytworzone z piasku luźnego drobnoziarnistego (wykorzystanego w eksperymencie) byłyby zaliczone do gleb o opadowo-retencyjnym typie zasilania wodą (OR). Przenosząc wyniki eksperymentu na realny profil glebowy można domniemywać, że nastąpiłoby opóźnienie odpływu wód opadowych przez profil glebowy z podsiąkiem kapilarnym w porównaniu do szybszego przepływu wody opadowej w głąb profilu glebowego bez podsiąku. Można uznać, że wyniki eksperymentu wskazują, iż podsiąk kapilarny wody gruntowej zwiększa wilgotność w profilu gleby wytworzonej z piasku luźnego. Na pewno dokładniejsze wyniki eksperymentu można uzyskać wydłużając rury z piaskiem, np. dwukrotnie do $150 \mathrm{~cm}$. Aby konstrukcja była rozbieralna i łatwa do pobierania próbek, należałoby połączyć dwie rury z eksperymentu tzw. mufą, nasuwką $\varnothing 110 \mathrm{~mm}$. 


\section{Wnioski}

Na podstawie obserwacji i wyników eksperymentu wykazano, że wpływ podsiąku kapilarnego na wilgotność profilu glebowego występuje także w glebach wytworzonych z piasku luźnego.

Przekładając wyniki eksperymentu na warunki zbliżone do właściwości gleb piaszczystych należy stwierdzić, że obecność wody gruntowej wpływa na produktywność gleb ze względu na dostęp systemu korzeniowego do wody w wyniku podsiąku kapilarnego.

W granicach leja depresyjnego, gdzie nie występuje oddziaływanie wód gruntowych, ograniczone są również możliwości wykorzystania wód opadowych.

Uprawy na glebach piaszczystych, o opadowo-retencyjnym typie gospodarki wodnej (OR), najbardziej odczuwają skutki hydrologiczne leja depresyjnego, które przejawiają się pogorszeniem warunków wilgotnościowych w glebie i ograniczeniem najlepszego wykorzystania wód opadowych.

\section{Literatura}

Baranowski, R., 1980. Wpływ gęstości gleby na jej agrofizyczne właściwości. Roczniki Gleboznawcze - Soil Science Annual 31 (2), 15-31.

Biskupski, A., Włodek, S., 2011. Oddziaływanie odkrywki Kopalni Węgla Brunatnego Bełchatów na uwilgotnienie gleb. Roczniki Gleboznawcze - Soil Science Annual 62 (2), 32-39.

Biskupski, A., Włodek, S., Pabin, J., 2008. Dynamika uwilgotnienia gleby w zasięgu leja depresji Kopalni Odkrywkowej Węgla Brunatnego - Bełchatów. Roczniki Gleboznawcze - Soil Science Annual 59(2), 18-24.

Branżowa Norma, 1978, Gleby i utwory mineralne - Podział na frakcje i grupy granulometryczne. PKN, BN-78/9180-11, Warszawa.

Grabowska-Olszewska, B., Siergiejew, J.M. (red.), 1977. Gruntoznawstwo. Wydawnictwo Geologiczne, Warszawa, 1-358.

Jeż, G., Jokiel, P., Maksymiuk, Z., Mela, S., Teodorski, J., 1997. Wpływ kopalni węgla brunatnego „Bełchatów” na stosunki wodne małej zlewni nizinnej. Acta Universitatis Lodziensis. Folia Geographica Physica 1, 127-153.

Komentarz do tabeli klas gruntów w zakresie bonitacji gleb gruntów ornych terenów równinnych, wyżynnych i nizinnych wraz z regionalnymi instrukcjami dotyczącymi gleb ornych terenów górzystych i komentarzami dotyczącymi użytków zielonych i gleb pod lasami dla użytku klasyfikatorów gleb i pracowników kartografii gleb IUNG, 1963. Ministerstwo Rolnictwa, 1-468.

Kowalik, P., 2001. Ochrona środowiska glebowego. Wydawnictwo Naukowe PWN, Warszawa, 1-258.

Kozek, M., Tomaszewski, E., 2018. Wieloletnia i sezonowa dynamika niżówek w Warcie w Sieradzu. Woda-Środowisko-Obszary Wiejskie $18(2), 41-56$.

Krajewski, R., Skawina, T., Żuławski, C., 1969. Hydrologiczno-glebowa metoda szacowania szkód w użytkach rolnych, wywołanych osuszającą działalnością górniczą. Ochrona Terenów Górniczych 9, 3-10.

Krysiak, S., Tołoczko, W., 2004. Zróżnicowanie krajobrazowe terenów nadpilicznych w okolicach Wielkopola. Acta Universitatis Lodziensis. Folia Geographica Physica 6, 71-90.

Laskowski, S., Tołoczko, W., 1995. Ocena stanu srodowiska glebowego w otoczeniu aglomeracji miejsko-przemyslowej Zgierza. Zeszyty Problemowe Postępów Nauk Rolniczych 418(1), 313-322.

Laskowski, S., Tołoczko, W., 1998. Zmiany odczynu i zawartości siarki w glebach objętych oddziaływaniem aglomeracji miejsko-przemysłowej Zgierza. Zeszyty Problemowe Postępów Nauk Rolniczych 456, 343-351.

Laskowski, S., Tołoczko, W., 2001. Alterations of some chemical and physico-chemical properties of selected soils in field ecosystems. Acta Agrophysica 50, 177-188.
Laskowski, S., Papińska, E., Tołoczko W., 2001a. Różnorodność przyrodnicza Załęczańskiego Parku Krajobrazowego na przykładzie wybranych stanowisk. Problemy Ekologii Krajobrazu, 9, 99-112.

Laskowski, S., Tołoczko, W., Rólka M., 2001b. Zawartość Pb, Zn, Cu w glebach przy drogach o różnym natężeniu ruchu w okolicach Łodzi. Acta Agrophysica 56, 137-144.

Laskowski, S., Tołoczko, W., 2003. Zawartość benzo/a/pirenu, antracenu i fenentrenu w glebach przy drogach o różnym natężeniu ruchu. Zeszyty Problemowe Postępów Nauk Rolniczych 493, 193-199.

Laskowski, S., Trawczyńska, A., Tołoczko, W., 2005a. Wpływ nawodnień na niektóre właściwości chemiczne mad bardzo lekkich doliny Neru. Inżynieria Ekologiczna 12, 205-206.

Laskowski, S., Trawczyńska, A., Tołoczko, W., 2005b. Content of iodine (127I) in chosen profiles of fen soils of the Pilica and Ner Valleys, [w:] Gworek, B. (red.), Obieg pierwiastków w przyrodzie, t. 3, 53-56.

Laskowski, S., Trawczyńska, A., Tołoczko, W., 2005c. Polycyclic aromatic hydrocarbons (PAHs) in arable soils in proximity of communication tracts near Łodz city. Chemia i Inżynieria Ekologiczna 12 (7), 709-715.

Laskowski, S., Trawczyńska, A., Tołoczko, W., 2006. Influence of irrigation on some chemical properties of very lightfan soils of the Ner Valley. Chemia i Inżynieria Ekologiczna 13 (1-2), 79-84.

Lekan, S., Terelak, H., 2000. Wpływ leja depresji hydrologicznej na gleby orne rejonu Bełchatowskiego Okręgu Przemysłowego. Roczniki Akademii Rolniczej w Poznaniu 317, Rolnictwo 56, 285-293.

Mosiej, J., 1989. Wpływ wilgotności gleby na plon traw w uprawie polowej. Zeszyty Problemowe Postępów Nauk Rolniczych 343, 207-213.

Niewiadomski, A., Tołoczko, W., Trawczyńska, A., 2009. Próchniczność oraz jej związki z buforowością i składem granulometrycznym gleb odłogowanych i użytkowanych rolniczo. Roczniki Gleboznawcze - Soil Science Annual 60 (1), 85-91.

Noworolnik, K., 2010. Plonowanie i jakość ziarna owsa w zależności od wilgotności podłoża i dawki azotu. Żyzność. Nauka. Technologia. Jakość 3 (70), 190-196.

Papińska, E., Tołoczko, W., 2002. Walory abiotyczne Załęczańskiego Parku Krajobrazowego, [w:] Kurowski, J.K., Witosławski, P. (red.), Funkcjonowanie parków krajobrazowych w Polsce. Wydawnictwo Uniwersytetu Łódzkiego, Łódź, 189-193.

PTG 2009, Klasyfikacja uziarnienia gleb i utworów mineralnych - PTG 2008. Roczniki Gleboznawcze - Soil Science Annual 60 (2), 5-16.

Rozporządzenie Rady Ministrów z dnia 12 września 2012 r. w sprawie gleboznawczej klasyfikacji gruntów z załącznikiem: Urzędowa tabela klas gruntów w zakresie bonitacji gruntów ornych, leśnych pod wodami i rekultywowanych terenów równinnych, wyżynnych i górskich (Dz.U., 2012, poz. 1246)

Sarnacka, S., Sokołowski, W., Lesiak, J., 1987. Wpływ głębokości odwodnienia spowodowanego przez Kopalnię Bełchatów na stosunki wodne gleb. Synteza badań przeprowadzonych w latach 1979-1985. Seria S, 55. Wydawnictwo IUNG, Puławy.

Smreczak, B., Łachacz, A., 2019. Typy gleb wyróżniane w klasyfikacji bonitacyjnej i ich odpowiedniki w 6. wydaniu Systematyki gleb Polski. Roczniki Gleboznawcze - Soil Science Annual 70 (2), 115-136.

Ślusarczyk, E., 1985a. Wpływ kopalni węgla brunatnego na stosunki wodne gleb w rejonie Bełchatowskiego Okręgu Przemysłowego. Cz. I: Oddziaływanie leja depresji hydrologicznej na wody gruntowe i wilgotność gleb. Pamiętniki Puławskie 85, 31-44.

Ślusarczyk, E., 1985b. Wpływ kopalni węgla brunatnego na stosunki wodne gleb w rejonie Bełchatowskiego Okręgu Przemysłowego. Cz. II: Typologia stosunków wodnych. Pamiętniki Puławskie 85, 45-60.

Tołoczko, W., Trawczyńska, A., Niewiadomski, A., 2009. Zawartość związków próchnicznych w glebach nawożonych preparatem EM. Roczniki Gleboznawcze - Soil Science Annual 60 (1), 97-101.

Tołoczko, W., Szmidt, A., 2018. Rędziny rezerwatu „Węże” w Załęczańskim Parku Krajobrazowym. Acta Universitatis Lodziensis. Folia Geographica Physica 17, 51-60.

Tomaszewski, E., 2011. Defining the threshold level of hydrological drought in lake catchments. Limnological Review 2, 81-89.

Tomaszewski, E., 2012. Wieloletnia i sezonowa dynamika niżówek w rzekach środkowej Polski. Wydawnictwo Uniwersytetu Łódzkiego, Łódź. 
Tomaszewski, E., 2014. Dynamika niedoborów odpływu niżówkowego w rzekach poddanych silnej antropopresji, [w:] Ciupa, T., Suligowski, R. (red.), Woda w mieście. Monografie Komisji Hydrologicznej PTG - t. 2, Instytut Geografii, Uniwersytet Jana Kochanowskiego w Kielcach, Kielce, 289-300.

Trawczyńska, A., Tołoczko, W., 2005. Content of heavy metals in ground water of the soil of Bzura river valley. Chemia i Inżynieria Ekologiczna 12 (1-2), 121-126.

Trawczyńska, A., Tołoczko, W., 2006. Content and profile arrangement of total and sulphate sulphur in soils of greenlands of the Bzura river valley. Chemia i Inżynieria Ekologiczna 13 (1-2), 139-145.

Trawczyńska, A., Tołoczko, W., 2007. Żyzność siedlisk leśnych w Gminie Ujazd. Ochrona Środowiska i Zasobów Naturalnych 31, 46-51.
Trawczyńska, A., Tołoczko, W., Niewiadomski, A., 2009. Zawartość pierwiastków śladowych w wodach górnej Bzury. Ochrona Środowiska i Zasobów Naturalnych 40, Warszawa, 491-496.

Wachowiak, G., 2004. Wpływ regresji leja depresyjnego KWB „Bełchatów” na wielkość odpływu w zlewni górnej Widawki. Górnictwo Odkrywkowe, Wydawnictwo Instytutu Górnictwa Odkrywkowego „Poltegor-Instytut” 46(1), 14-19.

Wroński, K., Tołoczko, W., 2008. Dziedzictwo nawodnień doliny Neru szansą na rozwój hodowli, [w:] Tołoczko, W. (red.), Dziedzictwo kulturowe, ochrona i adaptacja jako szansa na rozwój. Wydawnictwo Piktor, Łódź, 108-118. 